\title{
QUEEN'S
UNIVERSITY
BELFAST
}

\section{Dissolved organic matter differentially influences arsenic methylation and volatilization in paddy soils}

Yan, M., Zeng, X., Wang, J., Meharg, A. A., Meharg, C., Tang, X., Zhang, L., Bai, L., Zhang, J., \& Su, S. (2019). Dissolved organic matter differentially influences arsenic methylation and volatilization in paddy soils. Journal of Hazardous Materials, 388, [121795]. https://doi.org/10.1016/j.jhazmat.2019.121795

Published in:

Journal of Hazardous Materials

Document Version:

Peer reviewed version

Queen's University Belfast - Research Portal:

Link to publication record in Queen's University Belfast Research Portal

\section{Publisher rights}

Copyright 2019 Elsevier Ltd.

This manuscript is distributed under a Creative Commons Attribution-NonCommercial-NoDerivs License

(https://creativecommons.org/licenses/by-nc-nd/4.0/), which permits distribution and reproduction for non-commercial purposes, provided the author and source are cited.

\section{General rights}

Copyright for the publications made accessible via the Queen's University Belfast Research Portal is retained by the author(s) and / or other copyright owners and it is a condition of accessing these publications that users recognise and abide by the legal requirements associated with these rights.

Take down policy

The Research Portal is Queen's institutional repository that provides access to Queen's research output. Every effort has been made to ensure that content in the Research Portal does not infringe any person's rights, or applicable UK laws. If you discover content in the Research Portal that you believe breaches copyright or violates any law, please contact openaccess@qub.ac.uk. 
3 Mengmeng Yan ${ }^{\mathrm{a}, \mathrm{b}}$, Xibai Zeng ${ }^{\mathrm{a}}$, Ji Wang ${ }^{\mathrm{b}}$, Andy A. Meharg ${ }^{\mathrm{c}}$, Caroline Meharg ${ }^{\mathrm{c}}$, Xianjing Tang ${ }^{\mathrm{d}}$, Lili

4 Zhang ${ }^{\mathrm{e}}$, Lingyu Bai ${ }^{\mathrm{a}}$, Junzheng Zhang ${ }^{f}$, Shiming Su*

$6{ }^{a}$ Institute of Environment and Sustainable Development in Agriculture, Chinese Academy of

7 Agricultural Sciences/Key Laboratory of Agro-Environment, Ministry of Agriculture, Beijing 8 100081, P.R. China.

9 b School of Geography \& Environmental Science, Guizhou Normal University, Guiyang 550001, Guizhou Province, P.R. China.

11 ' Institute for Global Food Security, Queen's University Belfast, Biological Sciences, 19 Chlorine 12 Gardens, Belfast BT9 5DL, UK.

$13{ }^{d}$ Institute of Soil and Water Resources and Environmental Science, Zhejiang University, Hangzhou 14310058 , P.R. China.

15 e Shanghai Synchrotron Radiation Facility, Shanghai Advanced Research Institute, Chinese Academy of Sciences, Shanghai 201204, P.R. China. 150080, P.R. China.

20 
23 Academy of Agricultural Sciences, Zhongguancun South Street No 12, Beijing, 100081, P. R.

24 China.

25 Email: sushiming@caas.cn

26 Tel/Fax: +861082106009 
27 Abstract: The effect of dissolved organic matter (DOM), derived from composted pig manure or rice straw, on arsenic methylation and subsequent biovolatilization in paddy soils was investigated. Arsine production following pig manure DOM application was 2.7- and 9.6-fold higher than that of soils treated with rice straw DOM and the control, respectively. Trimethylarsine was the dominant arsine at $54 \%$, followed by dimethylarsine at $22 \%$, arsine at $21 \%$, and monomethylarsine at $3 \%$. The copy numbers of the total and As-methylating bacteria were significantly enhanced in paddy soils treated with DOM. Pig manure DOM altered soil bacterial profile by increasing the OTU number of As methylation-inducing bacteria, such as Proteobacteria, Bacteroidetes, Geobacter, Sphingomonas, Streptomyces, and Rhodopseudomonas, thereby promoting As volatilization and methylation in paddy soils. The higher relative content of alkyl-C, N-alkyl $\mathrm{C}$, and carboxyl-C in pig manure DOM was responsible for the increase in total and arsM-carrying bacteria in paddy soils, leading to enhanced As methylation. These observations will promote a better understanding of the role of DOM in mediating As methylation and volatilization, along with how organic fertilization affects straighthead disorder of rice, a condition caused by methylated arsenic species.

Keywords: Biotransformation; Pig manure; Arsine; arsM; High-throughput sequencing 


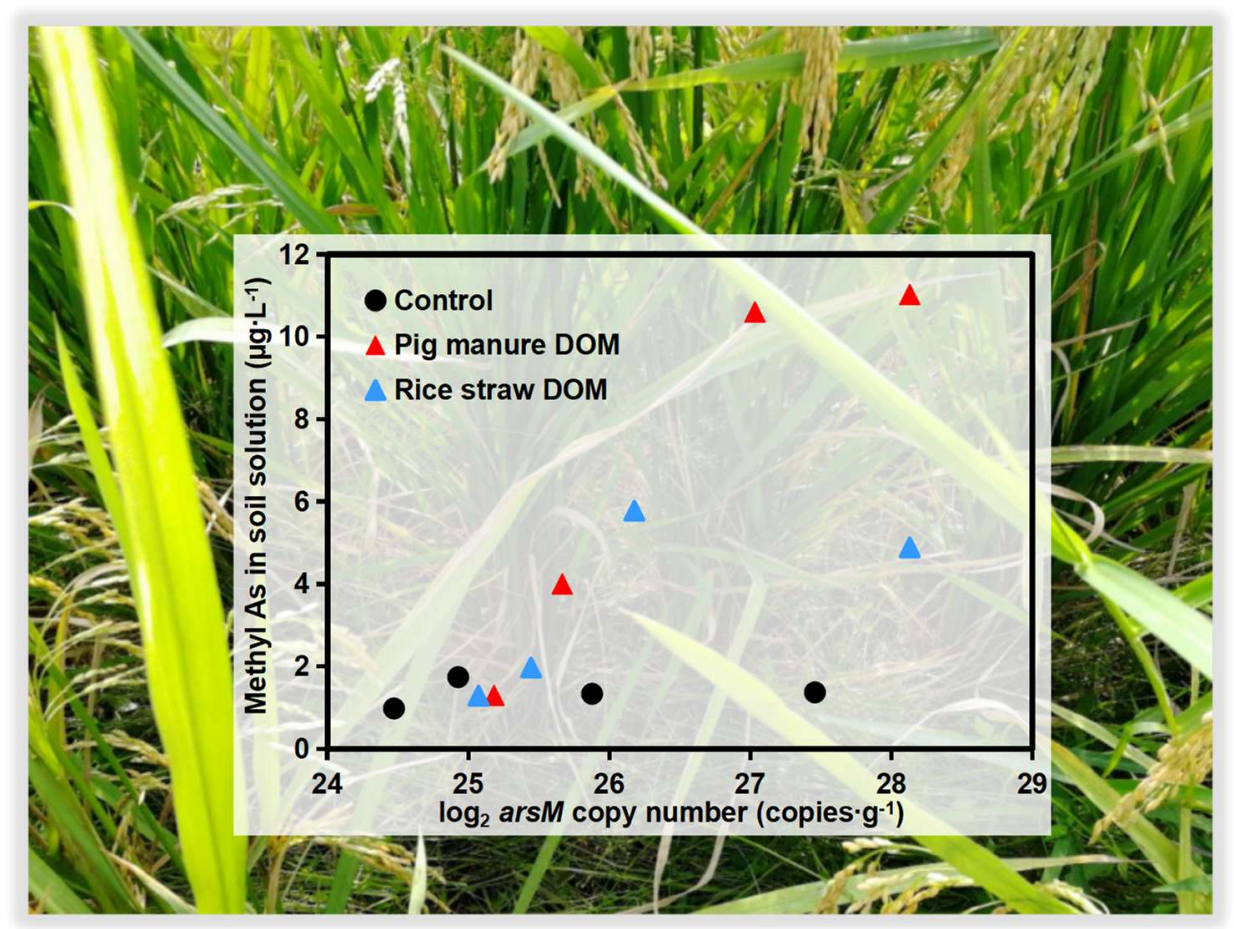


7

\section{Introduction}

Arsenic (As) present in soils is normally speciated as arsenite $[\mathrm{As}(\mathrm{III})]$ and arsenate $[\mathrm{As}(\mathrm{V})]$, termed together as inorganic arsenic (iAs), monomethylarsonic acid (MMAs), dimethylarsinic acid (DMAs), trimethylarsine oxide (TMAsO), and arsenic sulfide (Yuan et al., 2005). Arsenic is mobilized into soil solution under the reduced conditions of paddy cultivation (Meharg and Zhao, 2012), whereupon the rice crop readily assimilates mobilized As species as the phosphate and silicic acid analogues $\mathrm{As}(\mathrm{V})$ and $\mathrm{As}(\mathrm{III})$, respectively (Ma et al., 2008; Kamiya et al., 2013). Rice grain contains approximately 10 -fold elevated levels of As compared to that in most crops; thus, consumption of rice represents the major source of human iAs intake through the food-chain (Li et al., 2011; Williams et al., 2006).

Grain As is dominated by iAs and DMAs species (Meharg et al., 2009). The ratio between inorganic and organic As in rice grains varies among different regions (Zhu et al., 2008; Williams et al., 2005). DMAs leads to straighthead disorder, ultimately decreasing rice yield (Zavala et al., 2008). DMAs is not synthesized in plants, being only generated by soil microbes (Qin et al., 2006). It is not well assimilated by roots yet once within the plant, DMAs is readily translocated to grain (Arao et al., 2011). Microbes methylate iAs sequentially through S-adenosylmethionine (SAM), encoded by the commonly found arsM gene, to produce MMAs, DMAs, and TMAsO (Qin et al., 2006; Qin et al., 2009; Zhao et al., 2013a). These species can be further reduced to their corresponding arsines, which are volatile species that can be lost from soils (Wang et al., 2014).

Organic matter plays a crucial role in the As methylation in paddy soils (Huang et al., 2012). The 
degree of As volatilization in soils amended with composted cereal straw was twice that obtained upon alfalfa compost supplementation (Huang et al., 2012). The addition of organic matter regulates microbial activities in soil by both providing an energy source and by depleting oxygen through this consumption, driving soils to be more reducing (Jia et al., 2013a). This affects As oxidation status and enhances methylation (Huang et al., 2012; Edvantoro et al., 2004; Mohapatra et al., 2008). Moreover, because the surface of dissolved organic matter (DOM) is normally negatively charged, it can compete with $\mathrm{As}(\mathrm{V})$ for the adsorption sites on the surface of soil colloids and facilitate the desorption of As to the soil solution (Mohapatra et al., 2007). In addition, DOM can enhance the mobility of As by forming a direct bond between As and a positively charged amino group on the surface of DOM (Saada et al., 2003). DOM in soil can also act as an electron donor or acceptor in redox reactions, thereby becoming directly involved in As reduction and oxidation (Dong et al., 2014; Jie et al., 2009). DOM from various sources exhibits distinctive differences in the composition of reactive functional groups (Zhang et al., 2018). Furthermore, as an effective source of carbon and nitrogen for microorganisms, DOM influences the soil microbial community structure (Goldberg et al., 2017), with soil microbes tending to have more interaction with DOM molecules following organic matter input (Li et al., 2019).

In the present study, the nature of DOM and arsM abundance and diversity were related to As methylation and biovolatilization. We hypothesized that the diversity in DOM characteristics differentially influences As methylation and volatilization by modifying the substrate and ars $M$-carrying bacterial community in paddy soils. The findings have important implications for a better understanding of DOM-mediated promotion of As methylation and the future selective 
application of organic fertilizer in paddy soils.

\section{Materials and methods}

\subsection{Experimental soil and DOM}

A Quarternary bedrock-derived red soil, pH 5.0, was collected from paddy soil contaminated with As from realgar mining, Shimen County, Hunan Province (N 29038', E 111이'). The total and available As content was approximately 60 and $1.45 \mathrm{mg} \cdot \mathrm{kg}^{-1}$, respectively. The available As in soil was extracted with $0.5 \mathrm{M} \mathrm{NaHCO}_{3}$ (Woolson et al., 1971) and analyzed using a hydride generation-atomic fluorescence spectrometer (HG-AFS, 9120, Beijing Titan Instrument Co., Ltd.). Other physical and chemical properties of the soils are provided in Table S1.

DOM samples were extracted from composted pig manure, chicken manure, and cow dung in addition to rice straw, and were labeled as PD, CMD, CDD, and RD, respectively. The pig manure, cow dung, and chicken manure were dried naturally, ground, and then sieved through a 20-mesh $(0.850 \mathrm{~mm})$ sieve. The rice straw was air-dried naturally and was cut into pieces of approximately $2 \mathrm{~cm}$ in length. DOM solutions of pig manure, cow dung, and chicken manure were prepared by leaching with ultrapure water (manure:water $=1: 10$ ) (Liu et al., 2014). The rice straw DOM solution was prepared by incubating with fresh soil extract for 60 days (Chen et al., 2018). The detailed extraction process and the physical and chemical properties of the DOM are provided in supporting information and Table S2-S5 and Fig. S1-S3. Comparatively, all DOM samples had approximately the same $\mathrm{H} / \mathrm{C}$ ratio of $0.15-0.17$ (Table S3). PD showed the lowest aromaticity, hydrophobicity, extent of humification, and average molecular mass, whereas RD had the highest 
113

values (Table S4). The relative abundance of carboxyl-C in animal-derived DOM was significantly higher than that in RD (Table S5). Animal-derived DOM contained more aliphatic alkane compounds such as alkyl-C and N-alkyl-C. RD contained the highest O-aryl-C and CDD had the highest aryl-C (Table S5). All prepared DOM was sterilized by $\mathrm{p}$-ray irradiation prior to the experiment.

\subsection{Incubation Experiment 1: Effect of DOM on the efficiency of As methylation in paddy soils}

The paddy soil was sieved through a $2-\mathrm{mm}$ sieve, of which $30 \mathrm{~g}$ was subsequently transferred to a 50-mL polyethylene centrifuge tube. DOM samples as $P D, C M D, C D D$, and $R D$ each with various concentrations of dissolved organic carbon (DOC) $\left(40,80,160\right.$, and $\left.320 \mathrm{mg} \cdot \mathrm{L}^{-1}\right)$ were added to individual centrifuge tubes. Flooding was imposed by maintaining a 2-cm water level above the soil surface. The centrifuge tubes were placed in an incubator at $25 \pm 1^{\circ} \mathrm{C}$ for 40 days, during which time ultrapure water was added by weighing to maintain constant water content. Sterile ultrapure water instead of DOM was used in the control treatment. Each treatment was repeated four times. After the incubation, the supernatant was extracted for the analysis of As speciation and DOC following centrifugation (4,052 $\mathrm{g}, 20 \mathrm{~min})$.

\subsection{Incubation Experiment 2: Effect of DOM on As volatilization in paddy soils}

Two types of DOM that had exhibited marked difference in the influence on As methylation in Experiment 1: pig manure DOM (PD-320) and rice straw DOM (RD-320), both with a TOC content of $320 \mathrm{mg} \cdot \mathrm{L}^{-1}$, were chosen for use in Experiment 2. Aliquots of air-dried paddy soils ( $200 \mathrm{~g}$ ) were placed in the conical flask of a volatile trapping device (Fig. S4). Silica gel beads impregnated with 
$10 \% \mathrm{AgNO}_{3}$, to trap volatile As (Huang et al., 2012), were placed at the mouth of the flask, below which were located three air inlets that transferred all volatile As to the trapping device along with the airflow. PD-320 and RD-320 solutions (200 mL) were added to separate conical flasks. The flood surface was maintained at a level of $2 \mathrm{~cm}$ higher than the soil surface. The water content was kept constant by weighing during the incubation. The soil was incubated in darkness at $25 \pm 1^{\circ} \mathrm{C}$ for 13 weeks. Sterile ultrapure water rather than DOM was used in the control treatment. Samples containing only the two types of DOM were established as blanks to eliminate the effect of the DOM itself. Each treatment was repeated three times. After 1, 5, 9, and 13 weeks of incubation, $5 \mathrm{~g}$ of soil samples and $5 \mathrm{~mL}$ of supernatants were collected and stored in a freezer at $-80^{\circ} \mathrm{C}$. The soil samples collected were used to extract DNA for the molecular biological analysis, whereas the supernatants were used to determine the As speciation. Soil pH and redox potential (Eh) were measured in-situ after 13-week incubation. Collected silica gel beads were added to aqua regia $\left(1: 3 \mathrm{HNO}_{3}: \mathrm{HCl}\right)$, from which we obtained digestion after $2 \mathrm{~h}$ at $100^{\circ} \mathrm{C}$ (Agricultural Industry Standard of the People's Republic of China, NY/Y 1121.11-2006). This digestion was then used to determine the total As content. To further characterize the chemical speciation of volatile As, four weeks of additional incubation was performed. Volatile As bound on the silica gel beads was extracted in $1 \% \mathrm{HNO}_{3}$ (Huang et al., 2012). Following microwave digestion (TANK BASIC, SINEO, Shanghai, China) with the following program: $60^{\circ} \mathrm{C}$ for $10 \mathrm{~min}, 80^{\circ} \mathrm{C}$ for $10 \mathrm{~min}$, and $100{ }^{\circ} \mathrm{C}$ for $30 \mathrm{~min}$ with $5 \mathrm{~min}$ ramp time between each stage, As speciation was determined.

\subsection{Determination of total As and As speciation}


The As speciation in the soil supernatants and silica gel bead extracts was determined using high performance liquid chromatography-inductively coupled plasma mass spectrometry (HPLC-ICP-MS, PerkinElmer NexION 300X). The test solution was filtered through a 0.22- $\mu$ m filter and subsequently supplemented with $2 \% \mathrm{H}_{2} \mathrm{O}_{2}$ and allowed to rest for 15 min prior to the analysis (Mestrot et al., 2009). For quality control, As(III) standard solution (GBW08666) and DMAs standard solution (GBW08669) were detected once every ten samples. The recovery of different As speciation in the standard water sample was 91-102\%; The total As in the soil supernatants and silica gel bead extract was determined using HG-AFS. Mass balance, determined by comparing the sum of As speciations in soil supernatants with the total As value determined separately, was found to be within the range of $67-122 \%$.

Soil $\mathrm{pH}$ was measured in a solid-to-deionized water ratio of 1:2.5 using a digital $\mathrm{pH}$ meter (Thermo Orion 4 Star, Beverly, MA, USA). Soil Eh was measured prior to the soil solution collection via platinum electrodes, using $\mathrm{Ag} / \mathrm{AgCl}$ electrodes as references. The concentration of dissolved organic carbon (DOC) in the soil solution was determined using a TOC/N analyzer (multi N/C2100, Analytik Jena AG, Jena, Germany). The content of iron, manganese, and sulfur in the soil solution after filtered through a $0.22 \mu \mathrm{m}$ filter was analyzed using an inductively coupled plasma-optical emission spectrometer (ICP-OES, Optima 5300DV, Perkin Elmer, USA).

\subsection{Soil DNA extraction and quantitative PCR assay of $16 S$ rRNA and arsM}

The DNA in soil samples was extracted according to the procedures of the Fast DNA SPIN Kit for Soil DNA (MP Bio). The copy numbers of $16 \mathrm{~S}$ rRNA and arsM genes were determined using 
real-time quantitative PCR (iQ5 Thermocycler; BioRad). Primers and amplification procedures for 16S rRNA and ars $M$ are provided in supporting information. The linear standard curve in the quantitative assay was in the range of $R^{2}>0.99$. The amplification efficiency was $90-110 \%$. Only one characteristic peak was observed in the melt curve of the reaction product. Three biological replicates were performed for each sample. Details of the real-time quantitative PCR are provided in the supporting information.

\subsection{High-throughput sequencing of $16 S$ rRNA and arsM}

The V3-V4 hypervariable regions of the 16S rRNA and $\operatorname{ars} M$ genes were subjected to high-throughput sequencing using the Illumina MiseqPE300 sequencing platform. The latter, which more accurately and comprehensively reflects the bacterial community than terminal restriction fragment length polymorphism (T-RFLP) analysis (Zhang et al., 2015), has been widely used in bacterial community analysis (Reid et al., 2017). The V3-V4 region of the bacteria $16 \mathrm{~S}$ rRNA and arsM genes were amplified using respectively 338F (ACTCCTACGGGAGGCAGCA) /806R (GGACTACHVGGGTWTCTAAT) (Li et al., 2015) and arsMF (5'-TCYCTCGGCTGCGGCAAYCCVAC-3') /arsMR (5'-CGWCCGCCWGGCTTWAGYACCCG-3') (Jia et al., 2013). Purified amplicons were pooled in equimolar ratios and paired-end sequenced $(2 \times 300)$ on an Illumina MiSeq platform according to standard protocols. Raw paired-end reads were joined after the filtering of adaptors, low-quality reads, ambiguous Ns, and barcodes to generate clean joined reads. The sequences were clustered into operational taxonomic units (OTUs) at a similarity level of $97 \%$ via the uparse method. For $16 \mathrm{~S}$ amplicons, the rdp Classifier tool was used to classify representative sequences into different taxonomic groups based on the SILVA ribosomal RNA gene database. For arsM 
201

amplicons, the megablast method of blastn was used to classify representative sequences into different taxonomic groups based on the nucleotide sequence (NT) database. Details of PCR and data processing after sequencing are provided in the supporting information.

\subsection{Data analysis}

The As speciation data were processed using NexION software (PerkinElmer, Shelton, CT, USA). The graphs were plotted with the use of Origin 9 software. Univariate analysis of variance (ANOVA) and Duncan's multiple range test were performed using SPSS 22.0. The significance level for the latter was set at $P<0.05$. For high-throughput sequencing data, clustering analyses and principal coordinate analysis (PCOA) were applied based on the OTU information from each sample using $\mathrm{R}$ (ade4 package loaded with the relative count table) to examine the similarity between different samples. The heatmaps were generated with the top 20 OTUs using R (vegan package) to compare the membership and structure of communities in different samples. All data are expressed as the means \pm standard error (SE).

\section{Results}

3.1. Effect of DOM derived from different sources on the efficiency of As methylation in paddy soils

DOM derived from different sources vary in efficiency with regard to regulating As methylation in paddy soils. As TOC concentration in DOM increased, the amounts of iAs, MMAs, DMAs, and TMAsO were detected differentially. The content of organic As and total As in the soil solution decreased to some extent when DOM was applied at lower concentration. When $320 \mathrm{mg} \mathrm{TOC \cdot \textrm {L } ^ { - 1 }}$ 
223

224

DOM was added, the organic As accounted for $76,68,76$, and $62 \%$ of the total As in the soil solutions treated with $\mathrm{PD}, \mathrm{CMD}, \mathrm{CDD}$, and RD, respectively, representing approximately 2.2, 2.0, 1.7, and 1.6 times the quantity of organic As present in the control (Fig. S6). In addition, a significant positive correlation was observed between the TOC and the number of methyl groups bound to As in soil supernatants $(P<0.01)$ (Fig. S7). Similarly, the rate of As methylation was increased to a considerably greater extent with the addition of exogenous PD. The efficiency of As-methylation in soil solution per unit was found to be $0.006 \mu \mathrm{mol}$ methyl groups binding to As. However, a lower efficiency of As-methylation was observed by RD treatment, with $0.004 \mu \mathrm{mol}$ methyl groups binding to As.

\subsection{Trapped As in silica gel beads and speciation analysis}

Following the application of DOM, the As volatilization in the paddy soils was markedly enhanced, with the amount of As volatilization increasing substantively with time (Fig. 1a). Compared to the other treatments, PD-320-mediated promotion of As volatilization in paddy soils was the greatest at all observed time points. After 13 weeks of incubation, the trapped volatile As of treatment PD-320 was $2.5 \mu \mathrm{g}$, which was 2.7 and 9.6-fold that of RD-320 (0.93 $\mu \mathrm{g})$ and of the control $(0.26$ $\mu \mathrm{g})$, respectively. Further speciation analysis revealed that the trapped volatile As mainly comprised trimethylarsine (TMAs), dimethylarsine $\left(\mathrm{Me}_{2} \mathrm{AsH}\right)$, arsine $\left(\mathrm{AsH}_{3}\right)$, and monomethylarsine $\left(\mathrm{MeAsH}_{2}\right)$ (measured as their pentavalent derivatives of TMAsO, DMAs, iAs, and MMAs, respectively) (Fig. 1b). In comparison, the volatile As trapped from treatment PD-320 was dominated by TMAs $\left(16.1 \mu \mathrm{g} \cdot \mathrm{kg}^{-1}\right)$, which accounted for $54 \%$ of the total As trapped, followed by $\mathrm{Me}_{2} \mathrm{AsH}\left(6.4 \mu \mathrm{g} \cdot \mathrm{kg}^{-1}\right), \mathrm{AsH}_{3}\left(6.2 \mu \mathrm{g} \cdot \mathrm{kg}^{-1}\right)$, and $\mathrm{MeAsH}_{2}\left(1.0 \mu \mathrm{g} \cdot \mathrm{kg}^{-1}\right)$, which accounted 
for 22,21 , and $3 \%$ of the total As trapped, respectively. For treatment RD-320, the $\mathrm{AsH}_{3}, \mathrm{TMAs}$, $\mathrm{Me}_{2} \mathrm{AsH}$, and $\mathrm{MeAsH}_{2}$ content was 4.2, 2.8, 2.1, and $1.9 \mu \mathrm{g} \cdot \mathrm{kg}^{-1}$ respectively, accounting for 38, 25, 19 , and $18 \%$ of the total As trapped. For the control, no $\mathrm{Me}_{2} \mathrm{AsH}$ was detected, whereas the $\mathrm{AsH}_{3}$, $\mathrm{MeAsH}_{2}$, and TMAs content was 8.0, 0.72, and $0.49 \mu \mathrm{g} \cdot \mathrm{kg}^{-1}$, respectively, representing 87,8 , and $5 \%$ of the total As trapped.

\subsection{Arsenic speciation in paddy soil solution with time after DOM addition}

The amount of iAs, MMAs, DMAs, and TMAsO in the soil solution with pig manure DOM and straw DOM increased with time (Fig. 2). In the control, there was no apparent change in the amount of each of the As species with time. After 13 weeks of incubation, the iAs, MMAs, DMAs, and TMAsO content in PD-320-treated samples increased by approximately 1.6, 3.7, 17.8, and 2.9-fold, respectively, compared to that after one week. For the RD-320 treatment, the iAs, MMAs, DMAs, and TMAsO content increased by approximately 2.1, 5.9, 3.9, and 2.5-fold compared to that after one week, respectively. The content of iAs, MMAs, DMAs, and TMAsO was obviously higher in the soil solution following DOM addition than that in the control, especially at the later stage of incubation. Relatively higher methylated As was observed than inorganic As in soil solution following DOM addition. The ratio of methylated As reached approximately 74.9 and $59.8 \%$ of the total As in PD-320 and RD-320-treated samples, respectively, after 13 weeks of incubation.

In addition, after 13 weeks of flooded incubation, the $\mathrm{pH}$ and Eh of the treated soils were significantly different from those of the control (Fig. S8). The soil pH values of treatments PD-320 
and RD-320 were 7.23 and 7.02, which were 1.07 and 0.86 units higher than that of the control (6.16). The soil Eh values in treatments PD-320 and RD-320 were significantly lower than that of the control. The Eh in treatment PD-320 was $522.3 \mathrm{mV}$, which was the lowest among the DOM tested. For treatment RD-320 and the control, the soil Eh values were 612.0 and $699.7 \mathrm{mV}$, respectively. Furthermore, significantly positive and negative relationships between iAs in the soil solution with dissoluble iron $(P<0.05)$ and sulfur $(P<0.01)$ were observed, respectively, whereas the relationship between iAs in the soil solution and dissoluble manganese was not significant (Fig. S9).

\subsection{Abundance of $16 S$ rRNA and arsM in paddy soil after DOM addition}

The gene abundance of $16 \mathrm{~S}$ rRNA and arsM in the treated paddy soils was found to increase with time. Among all treatments, the gene abundance was the highest in treatment PD-320 (Fig. 3). After 13 weeks of incubation, the $16 \mathrm{~S}$ rRNA gene copy numbers $\left(\log _{2}\right)$ in treatments PD-320, RD-320, and control were $32.34,31.28$, and 29.91 copies $\cdot g^{-1} \cdot d r y$ soil, respectively, whereas the arsM gene copy numbers $\left(\log _{2}\right)$ were $29.47,28.13$, and 27.46 copies $\cdot g^{-1} \cdot d r y$ soil. The $16 S$ rRNA and arsM abundance of pig manure DOM-treated soil was significantly higher than that of straw DOM-treated soil and the control $(P<0.05)$. The relationship between ars $M$ copy number and organic As content was further analyzed (Fig. S10). The addition of exogenous pig manure DOM was the most effective in accelerating As methylation in paddy soils.

\subsection{Diversity of the total bacterial communities in paddy soils after DOM addition}

There were significant differences in the diversity of bacterial communities among various 
treatments after incubation for different durations. After nine weeks of incubation, the $\alpha$ diversity indices; for example, Chao, observed species, phylogenetic diversity whole tree, and Shannon indices of treatments PD-320 and RD-320 were considerably higher than those of the control $(P<0.05)$ (Table S6). The sequencing data was also analyzed using PCoA. Marked changes were observed in the bacterial community structures not only in each of the treatments as the cultivation time increased but also among treatments (Fig. S11a). In addition, notable differences occurred in the bacterial community structures at phylum and genus levels among treatments. At the phylum level, the sum of the relative abundances of six bacterial phyla; i.e., Proteobacteria (25-42\%), Firmicutes (8-36\%), Chloroflexi (4-21\%), Acidobacteria (6-13\%), Bacteroidetes (112\%), and Actinobacteria (3-16\%) exceeded $80 \%$ (Fig. S12). The abundance of Proteobacteria and Bacteroidetes in each treatment increased with time. In treatment PD-320, the abundance of Proteobacteria increased from a range of $25-32 \%$ in weeks $1-5$, to $36-42 \%$ in weeks $9-13$. The abundance of Bacteroidetes increased from 4\% in week 1 to $13 \%$ in week 13, both of which were considerably higher than that of the control and RD-320 in the same incubation period. The differences among various treatments at the genus level (top 20 in abundance) were further investigated (Fig. 4). The relative abundance of the unidentified was determined to be $42-68 \%$, indicating that as-yet-unidentified microbes at the genes level clearly predominated. We also identified genera including Clostridium_sensu_stricto_10 (0-5\%), Anaerolinea (0-5\%), Geobacter $(0-3 \%)$, and Sphingomonas $(1-4 \%)$ as genera with substantial predominance, in which the relative abundance of Geobacter in treatment PD-320 increased from $1 \%$ in week 1 to $3 \%$ in week 13, and that of Sphingomonas increased from $1 \%$ in week 1 to $4 \%$ in week 13 , with both of being considerably higher than that of the control and RD-320 at the same incubation time. 
313 Distinct differences were observed in the genetic diversity of ars $M$-carrying bacteria between DOM treatments and the control. The PD_whole_tree parameter of treatment PD-320 was significantly higher than those of RD-320 and control treatments $(P<0.05)$, except in the ninth week of incubation (Table S7). Analysis of the sequencing data using PCoA identified differential changes in the community structure of arsM-carrying bacteria in each of the treatments over incubation time and among treatments (Fig. S11b). At both phylum and genus levels, the community structures of arsM-carrying bacteria in soil differed among treatments. At the phylum level, the sum of the relative abundances of four of the bacterial phyla: Proteobacteria (28-41\%), unidentified (18-44\%), Actinobacteria (6-39\%), and Gemmatimonadetes (9-14\%) exceeded 90\%

(Fig. S13). The abundance of Proteobacteria in each of the treatments increased with cultivation time, among which the abundance of Proteobacteria in treatment PD-320 increased from $28 \%$ in week 1 to $41 \%$ in week 13, with both being significantly higher than those of control (30-37\%) and RD-320 (28-39\%) treatments in the same incubation period. The differences among the treatments at the genus level (top 20 in abundance) were also investigated (Fig. 5). The sum of the relative abundances of eight types of bacteria including unidentified (17-40\%), Rhodopseudomonas (18-34\%), Cellulomonas (1-35\%), Gemmatirosa (9-14\%), Rhodomicrobium (1-6\%), Sphaerobacter (1-5\%), Streptomyces (1-5\%), and Stackebrandtia (0-4\%) exceeded 90\%, among which the unidentified group and Rhodopseudomonas comprised the genera with marked predominance, accounting for $30-70 \%$ in each of the treatments. The abundances of 
higher than those in RD-320 and control treatments.

\section{Discussion}

Soil properties and agriculture practices perturb the biogeochemical cycle of As (Zhang et al., 2015; Zhu et al., 2017), with the responses to nitrate (Zhang et al., 2017), iron (Yang et al., 2018) and organic matter (Williams et al., 2011) being well characterized. DOM mediates the functional state of soil bacterial communities (Li et al., 2019); in the present study, its quality was shown to cause a differential response in arsM diversity. Accordingly, DOM also plays an important role in As adsorption, desorption, and transformation in paddy soils (Williams et al., 2011). In the present study, higher content of methylated As than iAs was obtained in soil solutions, especially following addition of pig manure DOM. This is consistent with the results of Afroz et al. (2019), who found considerably increased proportions of methylated As than iAs in manure-treated soils. In particular, the diversity in DOM characteristics might differentially influence As methylation by modifying the substrate in addition to the arsM-carrying bacterial community in paddy soils.

DOM addition directly or indirectly contributed to As release from the soil phase, especially at higher TOC concentration. The functional groups on the surface of DOM, such as carboxyls and hydroxyls, can directly perform ligand exchange with iAs (Mohapatra et al., 2007). Microbially reduced humics, particularly fulvic acid, act as an electron shuttles to promote As reduction and release (Qiao et al., 2019). In addition, DOM-mediated change in Eh and pH condition can also indirectly affect the adsorption affinities of solid-phase As in paddy soil (Redman et al., 2002). Soil Eh potentials drop whereas $\mathrm{pH}$ has a tendency to increase owing to the consumption of $\mathrm{H}^{+}$ 
355

356

357

(Frohne et al., 2011), which promotes the release of soil As into solution (Bennett et al., 2012). In the present study, a more significant decrease in the Eh and increase in $\mathrm{pH}$ was observed for soil supplemented with pig manure DOM. The release of solid-phase As from the soil to the solution was promoted, providing more substrates for As methylation in paddy soil.

Arsenic solubility is also associated with the biogeochemical processes of iron and sulfur (Zhu et al., 2017). In the present study, a significantly positive and negative relationship between iAs in soil solution and dissoluble iron $(P<0.05)$ and sulfur $(P<0.01)$ was observed, respectively. The reduction of iron oxide or hydroxide might be stimulated by the addition of DOM as a potential electron donor to result in the release of As and Fe in soil solution (Islam et al., 2004). The increase in dissoluble sulfur is conducive to reduce Fe and As solubility by forming pyrite $\left(\mathrm{FeS}_{2}\right)$, realgar (AsS), orpiment $\left(\mathrm{As}_{2} \mathrm{~S}_{3}\right)$, or arsenopyrite (FeAsS) (Kim et al., 2002; O'Day et al., 2004). Furthermore, when DOM was applied at lower concentration, total As in soil solution decreased to some extent. This may have occurred because the direct adsorption of DOM by soil colloid (Avneri-Katz et al., 2017) might compromise the contribution of ligand exchange with iAs to As release from the soil. DOM can also complex with As through the formation of metal-bridged soluble ternary As-Fe-DOM, reducing As solubility (Borggaard et al., 2019).

Paddy soil DOM characteristics significantly associate with the variances in microbial community (Li et al., 2018), being a direct source of carbon and energy (Li et al., 2019). DOM quality is also important with respect to microbial diversity (Guerrero-Feijóo et al., 2017; Li et al., 2019). The relative content of alkyl-, O-aryl, aryl-, and carbonyl-C can explain a large amount of the variation 
377

in soil microbial activity and composition (Ng et al., 2014). In the present study, compared to rice straw DOM, pig manure DOM exhibited a higher relative content of alkyl-C, N-alkyl C, and carboxyl-C and lower O-aryl-C, whereas no significant difference in the relative content of aryl-C among treatments was observed. Lower aromaticity, hydrophobicity, extent of humification, and average molecular mass were also found in pig manure DOM. Alkyl-C is mainly contained in lipids, waxes, cutins, suberins, lignin, and proteins (Baldock et al., 2004; Baumann et al., 2009) with $\mathrm{N}$-alkyl $\mathrm{C}$ being found in proteins and lignin (Baldock et al., 2004). Carboxyl-C, as the best predictor of soil microbial activity, is found in proteins and organic acids (Ng et al., 2014). Alkyl-C, $\mathrm{N}$-alkyl C, and carboxyl-C are important labile carbon forms whereas O-aryl-C and aryl-C are mainly associated with stabilized OM (Ng et al., 2014).

Pig manure DOM containing more labile $\mathrm{C}$ forms is readily assimilated by bacteria, whereas those containing more aromatic compounds such as rice straw DOM are less susceptible to microbial assimilation (Jamieson et al., 2014; Fellman et al., 2008). The differences in the nature of various types of DOM may reflect the differences in total bacterial and arsM-carrying bacterial abundance in treated paddy soils, leading to enhanced methylation. This was verified by the correlation between the efficiency of As methylation in soil solution and the relative content of total labile carbon (Fig S14a) or alkyl carbon in DOM (Fig S14b). Arsenic methylation was accelerated with the increase of total labile carbon to some extent $(P=0.13)$ whereas alkyl carbon significantly positively contributed to As methylation $(P<0.05)$. In particular, alkyl carbon, accounting for $25.7-32.5 \%$ of the carbon-containing functional groups in DOM and $53.1-61.3 \%$ of the total labile carbon, was the most crucial in promoting As methylation. 
400 Furthermore, the differences in nutrient input during DOM addition may also affect As

401 methylation. Here, we found that the content of total $\mathrm{K}$ and EC in pig manure DOM was lower

402 than that in rice straw DOM. No significant difference was found in total Fe or S between the two

403 types of DOM. The pig manure DOM exhibited higher total $\mathrm{N}$, total $\mathrm{P}$, and dissolved organic 404 nitrogen (DON) content (Table S8). These might help to improve the community of arsM-carrying 405 bacteria to some extent by providing nutrition sources, thereby enhancing As methylation.

406 Additional research is needed to explore the possible contribution of nutrient input. Nevertheless,

407 the selective application of rice straw rather than animal manure is suggested to limit As 408 methylation in paddy soils and avoid the DMAs-induced straighthead disorder of rice.

Pig manure DOM modified soil bacterial profile by increasing the OTU number of As methylation-inducing bacteria, thereby promoting As volatilization and methylation therein. In the present study, Proteobacteria and Bacteroidetes OTUs increased to become prominently

413 higher following pig manure DOM addition compared to those of control and straw DOM. Proteobacteria, which constitutes one of the dominant microorganisms in rice root systems (Mestrot et al., 2009; Knief et al., 2012), possesses a strong As methylation ability (Bennett et al., 2012); in addition, Bacteroidetes also contains the ars $M$ gene sequence and promotes As

417 methylation and volatilization in paddy soils (Jia et al., 2013b; Xiao et al., 2016). Geobacter and Sphingomonas were also prominent genera during cultivation following pig manure DOM application. Geobacter can mediate the dissimilatory reduction of $\mathrm{As}(\mathrm{V})$ to $\mathrm{As}(\mathrm{III})$, increasing the amount of substrate for As methylation (Qiao et al., 2018), whereas Sphingomonas promotes As 
421 methylation in the rice rhizosphere, thereby playing an important role in the As methylation and

422 volatilization in paddy soils (Knief et al., 2012; Liu et al., 2011). Based on arsM gene sequencing,

423 the presence of Sphingomonas and higher abundances of Streptomyces and Rhodopseudomonas

424 as dominant genera were also observed following pig manure DOM treatment. Streptomyces

425 have been found to participate in the As methylation in composts (Zhai et al., 2017). In turn,

426 Rhodopseudomonas palustris has a strong ability to methylate As (via RparsM) and can markedly

427 enhance As methylation and volatilization in paddy soils (Chen et al., 2014). The

428 as-yet-unidentified microbes also constituted the genera with absolute predominance of $16 \mathrm{~S}$

429 rRNA and arsM. This suggested that the unidentified microbes played an important role at the 430 genus level, necessitating further studies to understand their functions and characteristics.

\section{Conclusions}

433 In the present study, we found that the chemical characteristics of DOM were associated with As biotransformation and that the diverse nature of various types of DOM differentially influenced

435 As methylation and volatilization based on their effects on the substrate along with the 436 abundance and diversity of arsM-carrying bacteria in paddy soils. This result emphasizes the 437 considerable role of DOM and its effects in shaping the soil microbial profile. These observations 438 expand our knowledge regarding how As methylation is differentially promoted by the diverse C 439 forms in paddy soils. 
442 The authors are grateful for financial support from the National Foundation of Natural Science of

443 China, Grant No. 41671328, the Yong Elite Scientist Sponsorship Program by the China

444 Association for Science and Technology No.: 2015QNRC001, the Special Fund of the Chinese

445 Central Government for Basic Scientific Research Operations in the Commonweal Research

446 Institute, Project No. BSRF201904, the Science Innovation Project of the Chinese Academy of

447 Agricultural Science (CAAS-ASTIP-2016-IEDA), the Natural Science Foundation of Heilongjiang

448 Province (Key Projects), Project No. ZD2018003, and the Project of Science and Technology

449 Supporting Plan, Guizhou Province (Qian Sci. Co. [2017], No.2580). We also appreciate the help of

450 Shan Hong, Ph.D. at the Analysis Center of Institute of Environment and Sustainable

451 Development in Agriculture, Chinese Academy of Agricultural Sciences, for arsenic speciation

452 analysis in samples.

453

454 NOTES

455 Declarations of interest: none.

456 
457

458

459

460

461

462

463

464

465

466

467

468

469

470

471

472

473

474

475

476

477

\section{References:}

Afroz, H., Su, S.M., Carey, M., Meharg, A.A., Meharg, C., Inhibition of microbial methylation via arsM in the rhizosphere: Arsenic speciation in the soil to plant continuum. Environ. Sci. Technol. 2019, 53, 3451-3463. https://doi.org/10.1021/acs.est.8b07008.

Agricultural industry standard of the People's Republic of China, NY/Y 1121.11-2006, Soil Testing Part II: Method for determination of soil total arsenic.

Arao, T., Kawasaki, A., Baba, K., Matsumoto, S., 2011. Effects of arsenic compound amendment on arsenic speciation in rice grain. Environ. Sci. Technol. 45, 1291-1297. https:// doi.org/10.

1021/es1033316.

Avneri-Katz, S., Young, R.B., McKenna, A.M., Chen, H., Corilo, Y.E., Polubesova, T., Borch, T., Chefetz, B., 2017. Adsorptive fractionation of dissolved organic matter (DOM) by mineral soil: Macroscale approach and molecular insight. Org. Geochem. 103, 113-124. https://doi.org/10.1016/j.orggeochem.2016.11.004.

Baldock, J.A., Masiello, C.A., Gélinas, Y., Hedges, J.I., 2004. Cycling and composition of organic matter in terrestrial and marine ecosystems. Mar. Chem. 92, 39-64. https://doi.org/10.10 16/j.marchem.2004.06.016.

Baumann, K., Marschner, P., Smernik, R.J., Baldock, J.A., 2009. Residue chemistry andmicrobial community structure during decomposition of eucalypt, wheat and vetch residues. Soil Biol. Biochem. 41, 1966-1975. https://doi.org/10.1016/j.soilbio.2009.06.022.

Bennett, W.W., Teasdale, P.R., Panther, J.G., Welsh, D.T., Zhao, H.J., Jolley, D.F., 2012. Investigating arsenic speciation and mobilization in sediments with DGT and DET: A mesocosm evaluation 

of oxic-anoxic transitions. Environ. Sci. Technol. 46 , 3981-3989. https://doi.org/10.1021/es $204484 k$.

Borggaard O.K., Holm P.E., Strobel B.W., 2019. Potential of dissolved organic matter (DOM) to extract $\mathrm{As}, \mathrm{Cd}, \mathrm{Co}, \mathrm{Cr}, \mathrm{Cu}, \mathrm{Ni}, \mathrm{Pb}$ and $\mathrm{Zn}$ from polluted soils: A review. Geoderma. 343, 235246. https://doi.org/10.1016/j.geoderma.2019.02.041.

Chen, J., Sun, G.X., Wang, X.X., Lorenzo, V.D., Rosen, B.P., Zhu,Y.G., 2014. Volatilization of arsenic from polluted soil by pseudomonas putida engineered for expression of the $\operatorname{ars} M$ arsenic(III) S-adenosine methyltransferase gene. Environ. Sci. Technol. 48, 10337-10344. https://doi.or g/10.1021/es502230b.

Chen, X.X., Wang, X.H., Xue, Y.Y., Zhang, T.A., Li, Y.H., Hu, J.J., Tsang, Y.F., Zhang, H.S., Gao, M.T., 2018. Influence of rice straw-derived dissolved organic matter on lactic acid fermentation by Rhizopus oryzae. J. Biosci. Bioeng. 125, 703-709. https://doi.org/10.1016/j.jbiosc.2018.01. 004.

Dong, X.L., Ma, L.Q., Gressa, J.L., Harris, W., Li, Y.C., 2014. Enhanced Cr(VI) reduction and As(III) oxidation in ice phase: Important role of dissolved organic matter from biochar. J. Hazard. Mater. 267, 62-70. https://doi.org/10.1016/j.jhazmat.2013.12.027.

Edvantoro, B.B., Naidu, R., Megharaj, M., Merrington, G., Singleton, I., 2004. Microbial formation of volatile arsenic in cattle dip site soils contaminated with arsenic and DDT. Appl. Soil. Ecol. 25 , 207-217. https://doi.org/10.1016/j.apsoil.2003.09.006.

Fellman, J.B., D’Amore, D.V., Hood, E., Boone, R.D., 2008. Fluorescence characteristics and biodegradability of dissolved organic matter in forest and wetland soils from coastal 

temperate watersheds in southeast Alaska. Biogeochemistry. 88 , 169-184. https://doi.org/ $10.1007 /$ s10533-008-9203-x.

Frohne, T., Rinklebe, J., Diaz-Bone, R.A., Du L.G., 2011. Controlled variation of redox conditions in a floodplain soil: Impact on metal mobilization and biomethylation of arsenic and antimony. Geoderma. 160, 414-424. https://doi.org/10.1016/j.geoderma.2010.10.012.

Goldberg, S.J., Nelson, C.E., Viviani, D.A., Shulse, C.N., Church, M.J., 2017. Cascading influence of inorganic nitrogen sources on DOM production, composition, lability and microbial community structure in the open ocean. Environ. Microbiol. 19 , 3450-3464. https://doi.org $/ 10.1111 / 1462-2920.13825$.

Guerrero-Feijóo, E., Nieto-Cid, M., Sintes, E., Dobal-Amador, V., Hernando-Morales, V., A'Ivarez, M., Balagu'e, V., Varela, M.M., 2017. Optical properties of dissolved organic matter relate to different depth-specific patterns of archaeal and bacterial community structure in the North Atlantic Ocean. FEMS Microbiol. Ecol. 93, fiw224. http://orcid.org/0000-0002-952 4-6059.

Huang, H., Jia, Y., Sun, G.X., Zhu Y.G., 2012. Arsenic speciation and volatilization from flooded paddy soils amended with different organic matters. Environ. Sci. Technol. 46, 2163-2168. https://doi.org/10.1021/es203635s.

Islam, F.S., Gault, A.G., Boothman, C., Polya, D.A., Charnock, J.M., Chatterjee, D., Lloyd, J.R., 2004, Role of metal-reducing bacteria in arsenic release from Bengal delta sediments. Nature 430, 68-71. https://doi.org/10.1038/nature02638. 
519

520

521

522

523

524

525

526

527

528

529

530

531

532

533

534

535

536

537

538

539

540

Jamieson, T., Sager, E., Guéguen. C., 2014. Characterization of biochar-derived dissolved organic matter using UV-visible absorption and excitation-emission fluorescence spectroscopies. Chemosphere. 103, 197-204. https://doi.org/10.1016/j.chemosphere.2013.11.066.

Jia, Y., Sun, G.X., Huang, H., Zhu Y.G., 2013a. Biogas slurry application elevated arsenic accumulation in rice plant through increased arsenic release and methylation in paddy soil. Plant Soil. 365, 387-396. https://doi.org/10.1007/s11104-012-1391-4.

Jia, Y., Huang, H., Zhong, M., Wang, F.H., Zhang, L.M., Zhu, Y.G., 2013b. Microbial arsenic methylation in soil and rice rhizosphere. Environ. Sci. Technol. 47, 3141-3148. https://doi. org/10.1021/es303649v.

Jie, J., Bauer, I., Paul, A., Kappler, A., 2009. Arsenic redox changes by microbially and chemically formed semiquinone radicals and hydroquinones in a humic substance model quinone. Environ. Sci. Technol. 43, 3639-3645. https://doi.org/10.1021/es803112a.

Kamiya, T., Islam, M.R., Duan, G.L., Uraguchi, S., Fujiwara, T., 2013. Phosphate deficiency signaling pathway is a target of arsenate and phosphate transporter OsPT1 is involved in as accumulation in shoots of rice. Soil Sci. Plant Nutr. 59, 580-590. https://doi.org/10.1080/ 00380768.2013.804390.

Kim, M., Nriagu, J., Haack, S., 2002, Arsenic species and chemistry in groundwater of southeast Michigan. Environ. Pollut. 120, 379-390. https://doi.org/10.1016/S0269-7491(02)00114-8.

Knief, C., Delmotte, N., Chaffron, S., Stark, M., Innerebner, G., Wassmann, R., von Mering, C., Vorholt, J.A., 2012. Metaproteogenomic analysis of microbial communities in the phyllosphere and rhizosphere of rice. ISME J. 6, 1378-1390. https://doi.org/10.1038/ismej. 2011.192. 
541

Li, G., Sun, G.X., Williams, P.N., Nunes, L., Zhu, Y.G., 2011. Inorganic arsenic in Chinese food and its cancer risk. Environ. Inter. 37, 1219-1225. https://doi.org/10.1016/j.envint. 2011.05.007.

Li, H. Y., Wang, H., Wang, H.T., Xin, P.Y., Xu, X.H., Ma, Y., Liu, W.P., Teng, C.Y., Jiang, C.L., Lou, L.P., Arnold, W., Cralle, L., Zhu, Y.G., Chu, J.F., Gilbert, J.A., Zhang, Z.J.,2018. The chemodiversity of paddy soil dissolved organic matter correlates with microbial community at continental scales. Microbiome. 6, 187. https://doi.org/10.1186/s40168-018-0561-x.

Li, X.M., Chen, Q.L., He, C., Shi, Q., Chen, S.C., Reid, B.J., Zhu, Y.G., Sun. G.X., 2019. Organic Carbon Amendments Affect the Chemodiversity of Soil Dissolved Organic Matter and Its Associations with Soil Microbial Communities. Environ. Sci. Technol. 53, 50-59. https://doi. org/10.1021/acs.est.8b04673.

Li, Y., Zhang, Q., Zhang, F.F., Liu, R.X., Liu, H., Chen, F., 2015. Analysis of the microbiota of black stain in the primary dentition. PLoS One 10, e0137030. https://doi.org/10.1371/journal.pone. 0137030.

Liu, B., Li, Y., Zhang, X., Wang, J., Gao, M., 2014. Combined effects of chlortetracycline and dissolved organic matter extracted from pig manure on the functional diversity of soil microbial community. Soil Biol. Biochem. 74, 148-155. https://doi.org/10.1016/j.soilbio.20 14.03.005.

Liu, S., Zhang, F., Chen, J., Sun, G.X., 2011. Arsenic removal from contaminated soil via biovolatilization by genetically engineered bacteria under laboratory conditions. J. Environ. Sci. 23, 1544-1550. https://doi.org/10.1016/S1001-0742(10)60570-0.

Ma, J. F., Yamaji, N., Mitani, N., Xu, X.Y., Su, Y.H., McGrath, S.P. , Zhao, F.J., 2008. Transporters of arsenite in rice and their role in arsenic accumulation in rice grain. P. Natl. Acad. Sci. U. S. A. 
105, 9931-9935. https://doi.org/10.1073/pnas.0802361105.

Meharg, A.A., Williams, P.N., Adomako, E., Lawgali, Y.Y., Deacon, C., Villada, A., Cambell, R.C.J., Sun, G., Zhu, Y.G., Feldmann, J., Raab, A., Zhao, F.J., Islam, R., Hossain, S., Yanai, J., 2009. Geographical variation in total and inorganic arsenic content of polished (white) rice. Environ. Sci. Technol. 43, 1612-1617. https://doi.org/10.1021/es802612a.

Meharg, A.A., Zhao, F.J., 2012. Arsenic \& Rice; Springer, London.

Mestrot, A., Uroic, M.K., Plantevin, T., Islam, M.R., Krupp, E.M., Feldmann, J., Meharg, A.A., 2009. Quantitative and qualitative trapping of arsines deployed to assess loss of volatile arsenic from paddy soil. Environ. Sci. Technol. 43 , 8270-8275. https://doi.org/10.1021/es9018755.

Mohapatra, D., Mishra, D., Chaudhury, G.R., Das R.P., 2008. Removal of arsenic from arsenic rich sludge by volatilization using anaerobic microorganisms treated with cow dung. Soil Sediment Contam. 17, 301-311. https://doi.org/10.1080/15320380802007069.

Mohapatra, D., Mishra, D., Rout, M., Chaudhury, G.R., 2007. Adsorption kinetics of natural dissolved organic matter and its impact on arsenic(V) leachability from arsenic loaded ferrihydrite and Al-ferrihydrite. J. Environ. Sci. Heal. A. 42, 81-88. https://doi.org/10.1080/ 10934520601015792.

Ng E.L., Patti A.F., Rose M.T., Schefe C.R., Wilkinson K., Smernik R.J., Caragnaro T.R., 2014. Does the chemical nature of soil carbon drive the structure and functioning of soil microbial communities? Soil Biol. Biochem. 70 , 54-61. https://doi.org/10.1016/j.soilbio.2013.12.004.

O'Day, P.A, Vlassopoulos, D., Root, R., Rivera, N., 2004. The influence of sulfur and iron on dissolved arsenic concentrations in the shallow subsurface under changing redox conditions. P. Natl. Acad. Sci. USA. 101, 13703-13708. https://doi.org/10.1073/pnas.0402775101 
585

586

587

588

589

590

591

592

593

594

595

596

597

598

599

600

601

602

603

604

605

606

Qiao J.T., Li X.M., Li F.B., Liu T.X., Yong L.Y., Huang W.L., Sun K., Tong H., Hu M., 2019. Humic Substances Facilitate Arsenic Reduction and Release in Flooded Paddy Soil. Environ. Sci. Technol. 53, 5034-5042. https://doi.org/10.1021/acs.est.8b06333.

Qiao, J.T., Li, X.M., Hu, M., Li, F.B., Yong, L.Y., Sun, W.M., Huang, W.L., Cui, J.H., 2018. Transcriptional activity of arsenic-reducing bacteria and genes regulated by lactate and biochar during arsenic transformation in flooded paddy soil. Environ. Sci. Technol. 52, 61-70. https://doi.org/10.1021/acs.est.7b03771.

Qin, J., Lehr, C.R., Yuan, C.G., Le, X.C., McDermott, T.R., Rosen, B.P., 2009. Biotransformation of arsenic by a Yellowstone thermoacidophilic eukaryotic alga. P. Natl. Acad. Sci. U.S.A. 106, 5213-5217. https://doi.org/10.1073/pnas.0900238106.

Qin, J., Rosen, B.P., Zhang, Y., Wang, G.J., Franke, S., Rensing, C., 2006. Arsenic detoxification and evolution of trimethylarsine gas by a microbial arsenite S-adenosylmethionine methyltransferase. P. Natl. Acad. Sci. U.S.A. 103, 2075-2080. https://doi.org/10.1073/pn as.0506836103.

Redman, A.D., Macalady, D.L., Ahmann, D., 2002. Natural organic matter affects arsenic speciation and sorption onto hematite. Environ. Sci. Technol. 36, 2889-2896. https://doi. org/10.1021/es0112801.

Reid M.C., Maillard, J., Bagnoud, A., Falquet,L., Vo, P.L., Bernier-Latmani, R., 2017. Arsenic methylation dynamics in a rice paddy soil anaerobic enrichment culture. Environ. Sci. Technol. 51, 10546-10554. https://doi.org/10.1021/acs.est.7b02970.

Saada, A., Breeze, D., Crouzet, C., Cornu, S., Baranger, P., 2003. Adsorption of arsenic (V) on kaolinite and on kaolinite-humic acid complexes: role of humic acid nitrogen groups. 
607

608

Wang, P.P., Sun, G.X., Jia, Y., Meharg, A.A., Zhu, Y.G., 2014. A review on completing arsenic biogeochemical cycle: Microbial volatilization of arsines in environment. J. Environ. Sci. 26, 371-381. https://doi.org/10.1016/S1001-0742(13)60432-5.

Weng, L., Van Riemsdijk, W.H., Hiemstra, T, 2009. Effects of fulvic acids on arsenate adsorption to goethite: Experiments and modelling. Environ. Sci. Technol. 43, 7198-7204. https://doi.org/ 10.1021/es9000196.

Williams, P.N., Islam, M.R., Adomako, E.E., Raab, A., Hossain, S.A., Zhu, Y.G., Feldmanu, J., Meharg, A.A., 2006. Increase in rice grain arsenic for regions of Bangladesh irrigating paddies with elevated arsenic in groundwaters. Environ. Sci. Technol. 40, 4903-4908. https://doi.org/10.1021/es060222i.

Williams, P.N., Price, A.H., Raab, A., Hossain, S.A., Feldmann, J., Meharg, A.A., 2005. Variation in arsenic speciation and concentration in paddy rice related to dietary exposure. Environ. Sci. Technol. 39, 5531-5540. https://doi.org/10.1021/es0502324.

Williams, P.N., Zhang, H., Davison, W., Meharg, A.A., Hossain, M., Norton, G.J., Brammer, H., Islam, M.R., 2011. Organic matter-solid phase interactions are critical for predicting arsenic release and plant uptake in Bangladesh paddy soils. Environ. Sci. Technol. 45, 6080-6087. https://doi. org/10.1021/es2003765.

Woolson, E., Axley, J., Kearney, P., 1971. Correlation between available soil arsenic, estimated by six methods, and response of corn (Zea mays L.). Soil Sci. Soc. Am. J. 35, 101-105. https://doi:10.2136/sssaj1971.03615995003500010030x. 
Xiao, K.Q., Li, L.G., Ma, L.P., Zhang, S.Y., Bao, P., Zhang, T., Zhu, Y.G., 2016. Metagenomic analysis revealed highly diverse microbial arsenic metabolism genes in paddy soils with low-arsenic contents. Environ. Pollut. 211, 1-8. https://doi.org/10.1016/j.envpol.2015.12.023.

Yang, Y.P., Zhang, H.M., Yuan, H.Y., Duan, G.L., Jin, D.C., Zhao, F.J., Zhu, Y.G., 2018. Microbe mediated arsenic release from iron minerals and arsenic methylation in rhizosphere controls arsenic fate in soil-rice system after straw incorporation. Environ. Pollut. 236, 598-608. https: //doi.org/10.1016/j.envpol.2018.01.099.

Yuan, C.G., Jiang, G.B., He, B., 2005. Evaluation of the extraction methods for arsenic speciation in rice straw, oryzasativa L., and analysis by HPLC-HG-AFS. J. Anal. Atom. Spectrom. 20, 103-110. https://doi.org/10.1039/B416102E.

Zavala, Y.J., Gerads, R., Gürleyük, H., Duxbury, J.M., 2008. Arsenic in rice: II. Arsenic speciation in USA grain and implications for human health. Environ. Sci. Technol. 42, 3861-3866. http s://doi.org/10.1021/es702748q.

Zhai, W.W., Wong, M.T., Luo, F., Hashmi, M.Z., Liu, X.M., Edwards, E.A., Tang, X.J., Xu, J.M., 2017. Arsenic methylation and its relationship to abundance and diversity of ars $M$ genes in composting manure. Sci. Rep.-UK. 7, 42198. https://doi.org/10.1038/srep42198.

Zhang, J., Zhao, S.C., Xu, Y., Zhou, W.X., Huang, K., Tang, Z., Zhao, F.J., 2017. Nitrate Stimulates Anaerobic Microbial Arsenite Oxidation in Paddy Soils. Environ. Sci. Technol. 51, 4377-4386. https://doi.org/10.1021/acs.est.6b06255.

Zhang, S.Y., Zhao, F.J., Sun, G.X., Su, J.Q., Yang, X.R., Li, H., Zhu, Y.G., 2015. Diversity and abundance of arsenic biotransformation genes in paddy soils from Sourthern China. Environ. Sci. Technol. 49, 4138-4146. https://doi.org/10.1021/acs.est.5b00028. 
650

651

652

653

654

655

656

657

658

659

660

661

662

663

664

665

666

Zhang, X.Y., Li, Y.B., Feng, G., Tai, C., Yin, Y.G., Cai, Y., Liu, J.F., 2018. Probing the DOM-mediated photodegradation of methylmercury by using organic ligands with different molecular structures as the DOM model. Water Res. 138, 264-271. https://doi.org/10.1016/j.watres. 2018.03.055.

Zhao F.J., Harris E., Jia Y., Ma J., Wu L., Liu W.J., McGrath S.P., Zhou J.Z., Zhu Y.G., 2013a. Arsenic methylation in soils and its relationship with microbial ars $M$ abundance and diversity, and As speciation in rice. Environ. Sci. Technol. 47, 7147-7154. https://doi.org/10.1021/es304 $977 \mathrm{~m}$.

Zhu, Y.G., Sun, G.X., Lei, M., Teng, M., Liu, Y. X., Chen, N. C., Wang, L.H., Carey, A.M., Deacon, C., Raab, A., Meharg, A.A., Williams, P.N., 2008. High percentage inorganic arsenic content of mining impacted and nonimpacted Chinese rice. Environ. Sci. Technol. 42, 5008-5013. http s://doi.org/10.1021/es8001103.

Zhu, Y.G., Xue, X.M., Kappler, A., Rosen, B.P., Meharg, A.A., 2017. Linking Genes to Microbial Biogeochemical Cycling: Lessons from Arsenic. Environ. Sci. Technol. 51, 7326-7339. https://doi.org/10.1021/acs.est.7b00689.

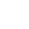


Figure 1. The trapped As with regard to time (a) and As speciation (b) in silicon beads after incubation in paddy soils. Control, without DOM; PD-320, pig manure DOM with TOC of 320 $\mathrm{mg} \cdot \mathrm{L}^{-1} ; \mathrm{RD}-320$, rice straw DOM with TOC of $320 \mathrm{mg} \cdot \mathrm{L}^{-1}$. Data are expressed as the means $\pm \mathrm{SE}$ $671(n=3)$.

Figure 2. Contents of different As speciation types in soil solution with time (weeks) after

673 different DOM addition in paddy soils. Control, without DOM; PD-320, pig manure DOM with TOC of $320 \mathrm{mg} \cdot \mathrm{L}^{-1} ; \mathrm{RD}-320$, rice straw DOM with TOC of $320 \mathrm{mg} \cdot \mathrm{L}^{-1}$. Data are expressed as the means $675 \pm \operatorname{SE}(n=3)$.

Figure 3. Abundance of As methylating bacteria $\left(a, \log _{2} \operatorname{ars} M\right)$ and total bacterial $\left(b, \log _{2} 16 S\right.$ 677 rRNA) in soil after incubation with different types of DOM. Control, without DOM; PD-320, pig manure DOM with TOC of $320 \mathrm{mg} \cdot \mathrm{L}^{-1}$; RD-320, rice straw DOM with TOC of $320 \mathrm{mg} \cdot \mathrm{L}^{-1}$. Data are expressed as the means $\pm \operatorname{SE}(n=3)$.

Figure 4. Heat map of the top 20 abundant genera (as determined by 16S rRNA sequence)

681 following each treatment. The color intensity in each cell indicates the transformed relative abundance by $\log _{2}\left(x^{*} 100+1\right)$ of the corresponding genus. The relative abundance is expressed as the average relative abundance of the three replicates in each treatment by the average percentage of the targeted sequences to the total high-quality bacterial sequences of each sample. Control, without DOM; PD-320, pig manure DOM with TOC of $320 \mathrm{mg} \cdot \mathrm{L}^{-1}$; RD-320, rice straw DOM with TOC of $320 \mathrm{mg} \cdot \mathrm{L}^{-1}$.

Figure 5. Heat map of the top 20 abundant genera (arsM-containing) in each treatment. The color intensity in each cell indicates the transformed relative abundance by $\log _{2}\left(x^{*} 100+1\right)$ of the 

the three replicates in each treatment by the average percentage of the targeted sequences to

691 the total high-quality bacterial sequences of each sample. Control, without DOM; PD-320, pig 692 manure DOM with TOC of $320 \mathrm{mg} \cdot \mathrm{L}^{-1}$; RD-320, rice straw DOM with TOC of $320 \mathrm{mg} \cdot \mathrm{L}^{-1}$.

693 
Figure 1.
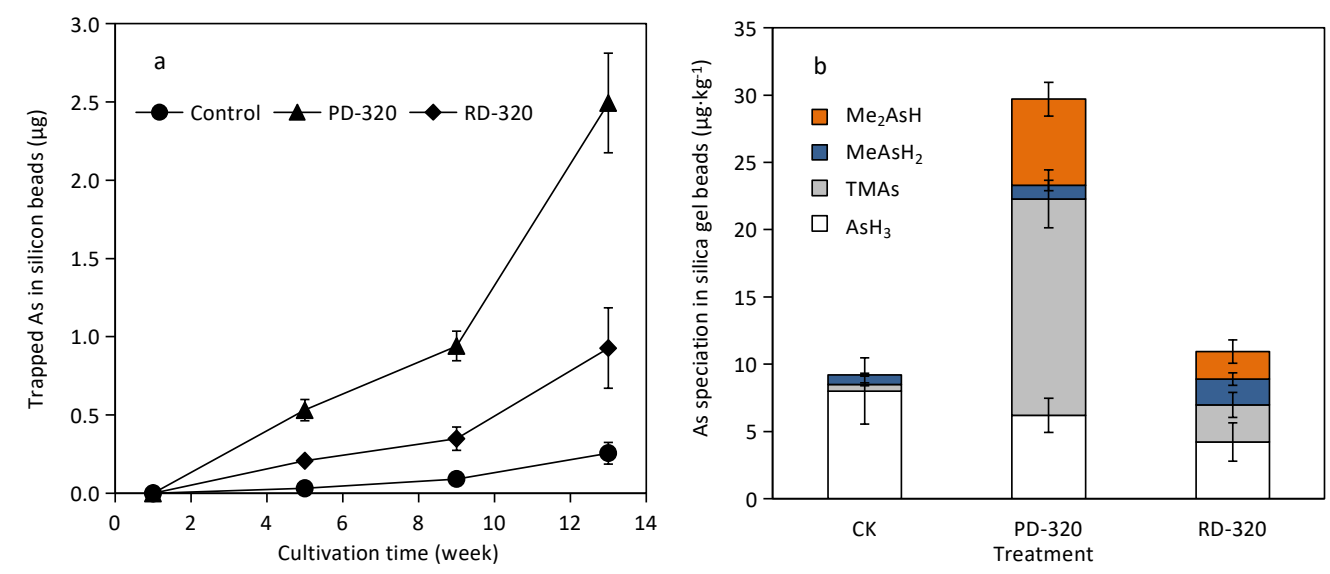

695

696

(Color will not be used in print)

697 
Figure 2.
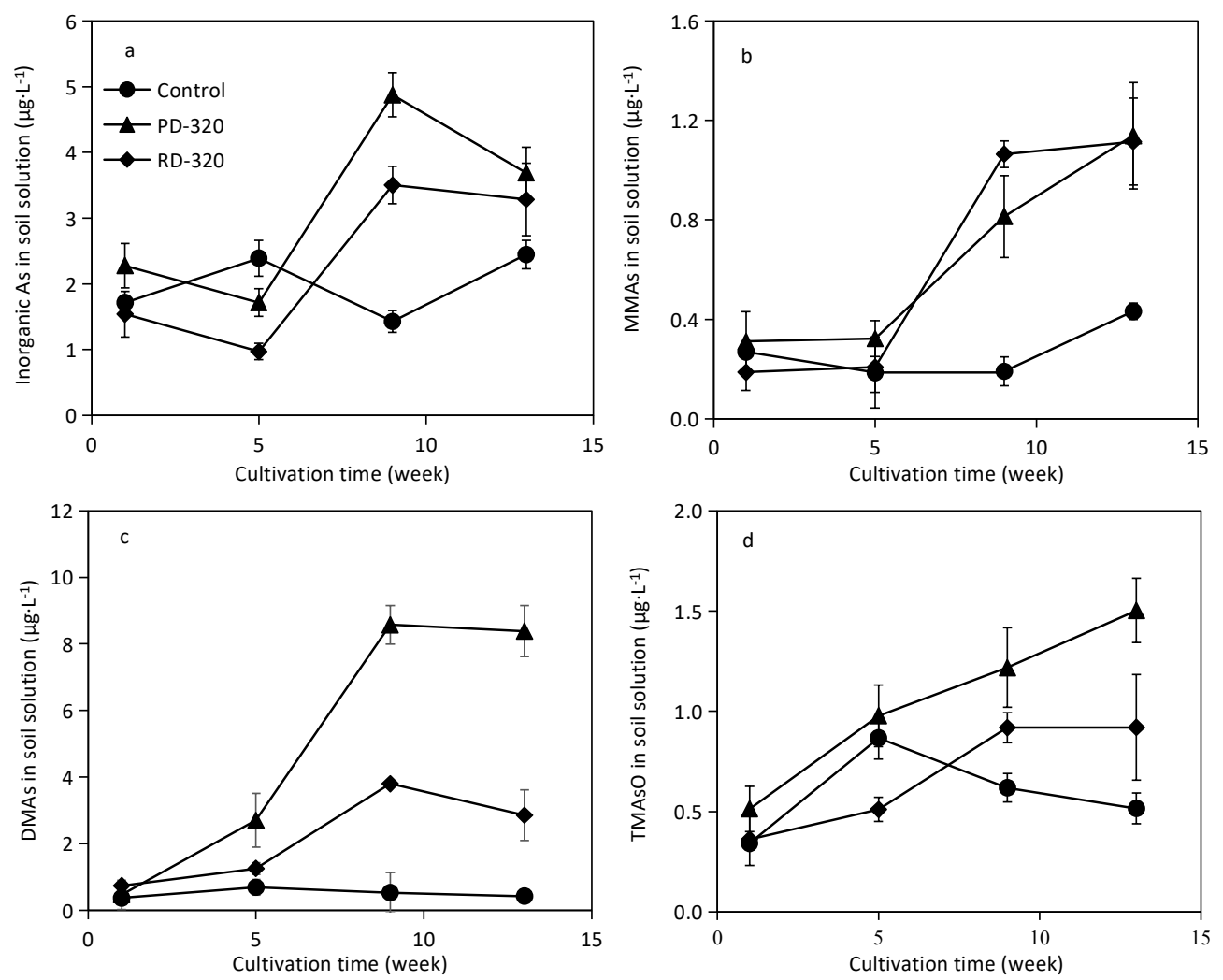

699 
Figure 3.
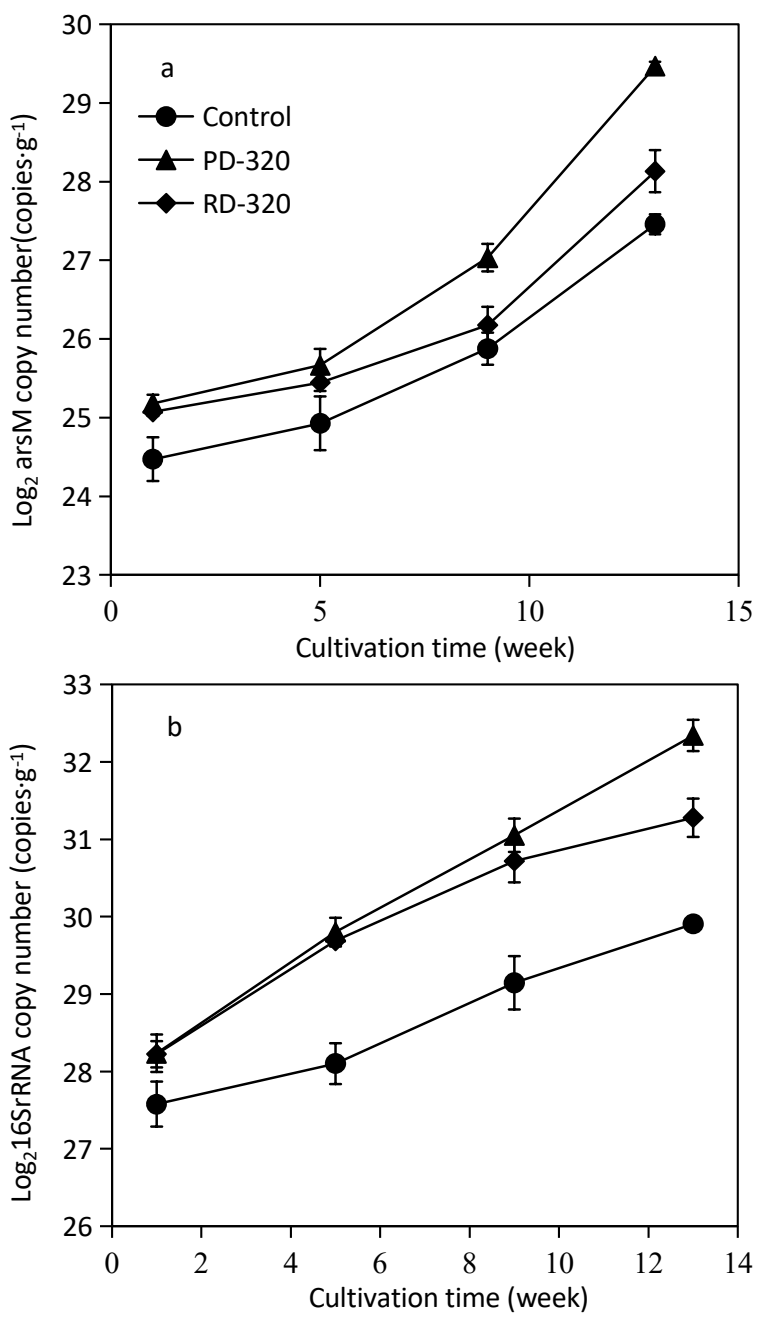

703 
Figure 4.

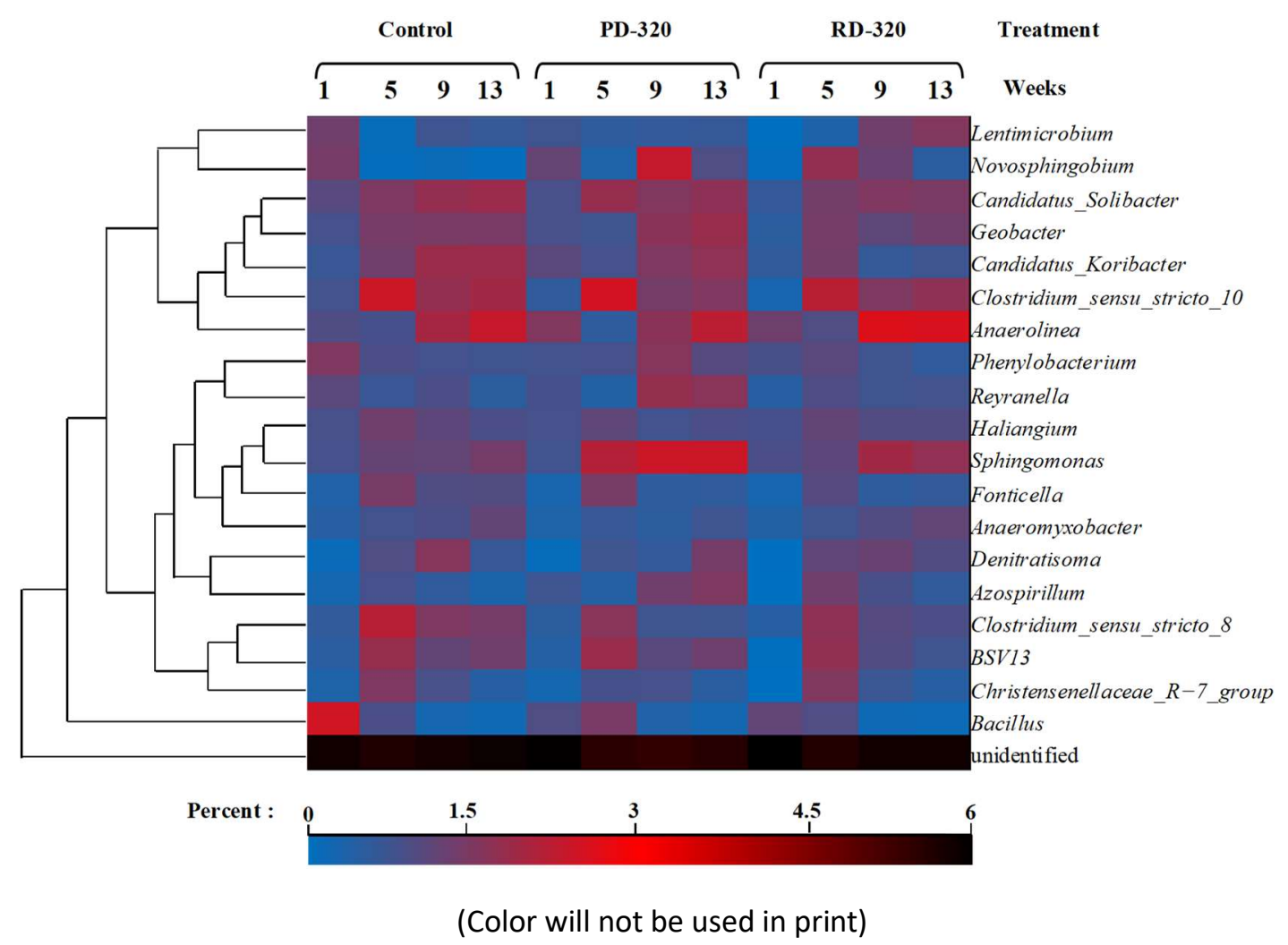


Figure 5.

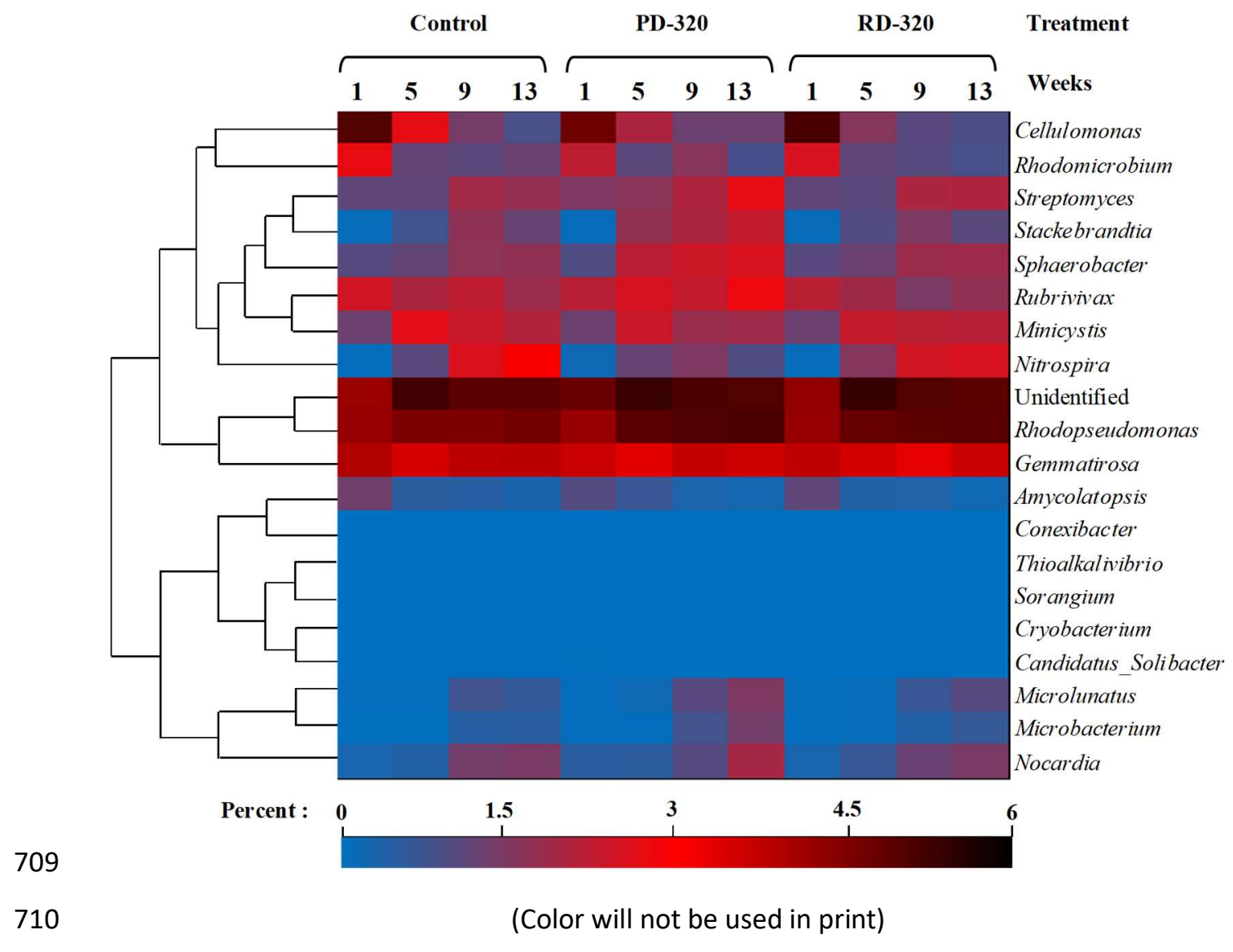

711 